\title{
AEROBIC BACTERIAL COUNTS ON HUMAN SKIN AFTER BATHING
}

\author{
R. J. HolT \\ Group Laboratories, Queen Mary's Hospital for Children, Carshalton, Surrey
}

SKIN bacteria live naturally in the outer keratinised layers of the epidermis (Kligman, 1965), and it follows that bathing with water or with dilute solutions of surface-active agents will remove many of them. This was amply demonstrated in the classical experiments of Price (1938) who used a technique of repetitive scrubbing with water to enumerate bacteria on selected surfaces of hands and forearms; from each series of viable-bacterial counts he constructed curves showing the cumulative totals of bacteria removed, and, by extrapolation, estimated the time needed for complete sterilisation. Davies and Noble $(1962,1963)$ showed convincingly that micro-organisms carried on the body surface are disseminated mainly on desquamated skin scales. The mechanical removal of these scales by washing from the outermost epidermal layer increases the bacterial count in the washing fluid, and may unmask bacteria hitherto secluded in the second and third keratinised layers. The use of an alkaline soap may help the removal of more bacteria by changing the electrostatic charge that secures bacteria to the squames (Pillsbury and Kligman, 1954).

These observations are well-founded, and indeed predictable, yet they appear to be in direct contradiction to the equally well-founded observations in almost every teaching laboratory that impression bacterial counts from fingers before and after scrubbing often reveal a considerable increase in the number of colonies (Gale et al., 1962). The experiments reported here were undertaken in the hope of reconciling these paradoxical observations (see also Holt, 1969).

\section{MeTHODS \\ Liquid elution counts}

Conventional plate-count procedures in which a simple diluent is used (Miles, Misra and Irwin, 1938) yield counts of viable units or aggregations of bacteria; where several live bacteria are aggregated in each unit the count is inaccurately low. Williamson and Kligman (1965) tested 16 non-ionic detergents for their ability to disperse bacterial aggregations and concluded that the most effective was Triton X100, a polyethane oxyalkyl phenol (Rohm and Haas Ltd*). They established that a concentration of 0.1 per cent. of the agent in $0.067 \mathrm{M}$ phosphate buffer at $p \mathrm{H} \mathrm{7.9}$ yielded maximal counts of skin bacteria when used in a modification of the scrub technique described by Pachtman, Vicher and Brunner (1954). This was largely confirmed in experiments here; the optimal $p \mathrm{H}$ was found to be about $7 \cdot 6$, and infusion broth with $0 \cdot 1$ per cent. Triton X100 gave higher recovery counts than were obtained with phosphate buffer (Holt, 1969).

The following scrub procedure was therefore used.

Received 22 May 1970; accepted 26 Nov. 1970.

* Supplied in UK by Lennig Chemicals Ltd, 26-28 Bedford Row, London, W.C.1.

J. MED. MICROBIOL.-VOL. 4 (1971) 
(a) Open-ended glass cylinders were cut from tubing of internal diameter $13.8 \mathrm{~mm}$; this gave an internal cross-sectional area of $150 \mathrm{~mm}^{2}$. The tubes, approximately $20 \mathrm{~mm}$ long, were wrapped in Kraft paper and autoclaved.

(b) The tube was held firmly against the skin site under investigation, $1 \mathrm{ml}$ of infusion broth containing $0 \cdot 1$ per cent. Triton X100 was introduced from a pipette into the cylinder and the skin surface was rubbed firmly and regularly for $1 \mathrm{~min}$. with the pipette tip. A small amount of fluid entered the pipette and was expelled at 10-s intervals.

(c) When this stage was completed, all the fluid was withdrawn from the cylinder and placed in a screw-capped 5-ml bottle; dilutions of 1 in 10, 1 in 100, and 1 in 1000 were made from this fluid into broth containing $0 \cdot 1$ per cent. surfactant. All procedures were carried out rapidly, but care was taken to mix each dilution vigorously.

(d) A dropper-pipette was calibrated with the actual fluid used for the scrub, and four separate drops from each dilution were distributed on dried nutrient-agar plates. After aerobic incubation for $24 \mathrm{hr}$ at $37^{\circ} \mathrm{C}$ the number of colonies in each drop area was counted; wherever colonies had coalesced, an estimate of their number was made after examination under low-power magnification.

(e) The count per $\mathrm{cm}^{2}$ of skin was calculated as the mean of 4 drop-counts $\times$ reciprocal of dilution $\times$ (drops per $\mathrm{ml}$ from pipette) $\div 1 \cdot 5$.

It was essential that the colony counts from each drop area were within reasonable limits; if the initial suspension was homogeneous and well mixed, the number of colonies in each drop had a Poisson distribution for which mean and variance were equal. On the advice of Dr G. B. Hill (personal communication) a control table was constructed to check variability by means of the number of samples examined. Any group of counts of drop cultures for which the range was found to be greater than the upper limit or less than the lower limit was ignored, because the Poisson distribution was suspect, and the whole procedure was repeated.

Another series of experiments showed that the bacterial counts on closely adjacent areas on normal unspecialised skin exposed to uniform conditions were usually within the range of \pm 15 per cent. about the mean of such counts; the reason for these investigations was that, in the bathing experiments detailed below, it was necessary to sample adjacent skin areas rather than take counts from the same area in close time-succession.

\section{Velvet pad imprint technique}

Sterilised velvet pads, backed with heavy aluminium foil (Holt, 1966) were used throughout; each pad was moistened with sterile infusion broth just before use, and was firmly applied to the skin surface without lateral movement. After about $10 \mathrm{~s}$ the pad was removed, and evenly pressed on the culture medium; great care was needed to avoid smearing the pad across the agar surface, because this produced "tailed" or duplicate colonies. The agar plates, usually two each of 5 per cent. horse-blood agar and MacConkey agar (Oxoid), were incubated aerobically for $48 \mathrm{hr}$ at $37^{\circ}$. The colonies were counted and the result was divided by 16 , to give the mean colony count per $\mathrm{cm}^{2}$.

\section{RESULTS}

Velvet-pad cultures were taken from five body sites on an adult male 5 min. before bathing in hot water with non-medicated toilet soap. Five minutes after drying by dabbing-not rubbing-with a freshly laundered towel, the pad cultures were repeated. The pads were $4 \times 4 \mathrm{~cm}$ in size. The results (table I) show that the counts increased 2.1-3.5 times after bathing.

The increase in colony count in all areas clearly merited further investigation, so more tests were made at the same sites on the same subject. After a bath in water at about $50^{\circ} \mathrm{C}$ with a non-medicated soap rubbed on each body site for $30 \mathrm{~s}$, followed by a rinse in water, the body was thoroughly dried. This 
time both imprint and liquid scrub counts were performed; the pad imprint was always taken first and the scrub sample was taken from a smaller area in the middle of the imprint area. These samples were taken just before bathing, and at $5 \mathrm{~min} ., 5 \mathrm{hr}, 10 \mathrm{hr}$ and $25 \mathrm{hr}$ after bathing.

The area of the pads was $30 \mathrm{~cm}^{2}(6 \times 5 \mathrm{~cm})$ and the liquid samples were taken from $1.5 \mathrm{~cm}^{2}$ within the padded area. The results are shown in table II. At each of the sites the area colony count was increased immediately after washing, in three cases almost four-fold. In contrast the scrub count of bacteria per unit area was somewhat decreased, although not by so large a factor. The colony counts reverted to pre-wash values after about $10 \mathrm{hr}$; the total bacterial count on three sites exceeded the pre-wash value within $10 \mathrm{hr}$.

TABLE I

Bacterial colony counts from skin by imprint method before and after bathing with water and soap

\begin{tabular}{l|c|c|c|c|c}
\hline & \multicolumn{2}{|c|}{ Number of colony-forming units of micro-organisms per cm² cultured from } \\
\cline { 2 - 6 } $\begin{array}{c}\text { Time from } \\
\text { bathing }\end{array}$ & $\begin{array}{c}\text { left } \\
\text { anterior } \\
\text { axilla } \\
\text { (relatively } \\
\text { hairless) }\end{array}$ & $\begin{array}{c}\text { abdomen } \\
\text { above } \\
\text { umbilicus }\end{array}$ & $\begin{array}{c}\text { left } \\
\text { groin } \\
\text { (hairless) }\end{array}$ & $\begin{array}{c}\text { left } \\
\text { lower shin } \\
\text { (almost } \\
\text { hairless) }\end{array}$ & $\begin{array}{c}\text { left } \\
\text { anterior } \\
\text { forearm } \\
\text { (hairless) }\end{array}$ \\
\hline 5 min. before & 14 & 2.7 & 3.2 & 6.8 & 1.5 \\
5 min. after & 29 & 7.2 & 9.1 & 22.0 & 4.4 \\
\hline $\begin{array}{c}\text { Increase after } \\
\text { bathing }\end{array}$ & $\times 2.1$ & $\times 2.7$ & $\times 2.8$ & $\times 3.2$ & $\times 2.9$ \\
\hline
\end{tabular}

Since this effect might be attributable either to the mechanical action of washing with water, or to the surfactant effect of the soap, the experiment was repeated by bathing the lower shin of the same subject (i) in plain warm water, and (ii) a week later, in hot water containing approximately 0.01 per cent. household detergent ("Stergene"). The long interval between these experiments was intended to allow bacteria on this site to settle back to normal distribution. The results (table III) showed that bathing with water increased the area colony count by 2.4 times, with a relatively small decrease in the bacterial (scrub) count; soon after bathing with dilute Stergene, the colony count increased nine-fold and the bacterial count dropped to a third of the pre-bathing count.

Similar experiments were made on two babies (table IV); scrub and imprint counts were taken from the interscapular region and from the left axilla. These cultures were taken immediately before and after bathing in warm water with non-medicated toilet soap; no talc was applied. In one case it was also possible to obtain cultures $24 \mathrm{hr}$ after bathing. Area colony counts from the interscapular region of the younger baby showed an increase of 2.3 times, and 


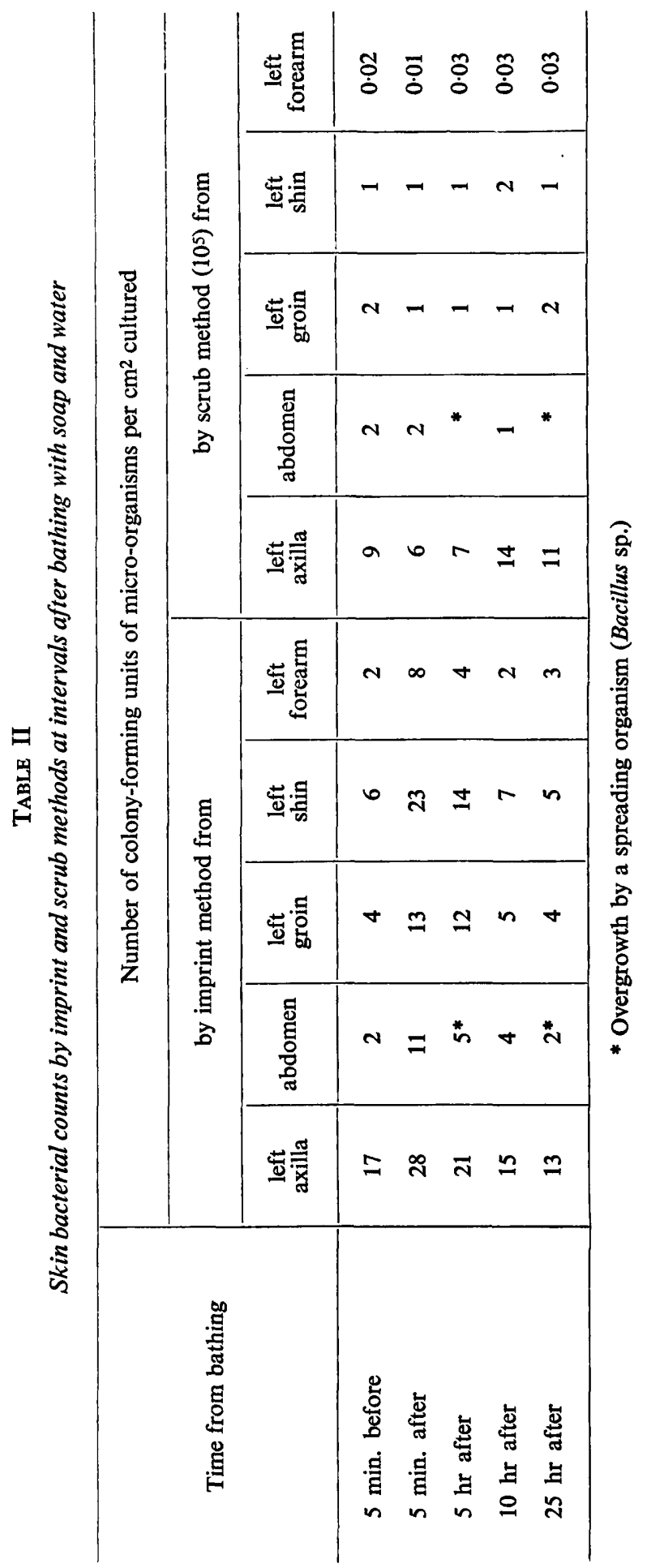


a decrease in the total bacterial count by a similar factor; after bathing, the colony count from this baby's axilla showed little increase, but the bacterial

TABLE III

Skin bacterial counts on lower shin after bathing in water and in dilute detergent

\begin{tabular}{|c|c|c|c|c|}
\hline \multirow{3}{*}{$\begin{array}{l}\text { Time from } \\
\text { bathing }\end{array}$} & \multicolumn{4}{|c|}{$\begin{array}{l}\text { Number of colony-forming units of micro-organisms } \\
\text { per } \mathrm{cm}^{2} \text { cultured from skin }\end{array}$} \\
\hline & \multicolumn{2}{|c|}{$\begin{array}{l}\text { by imprint method after } \\
\text { bathing in }\end{array}$} & \multicolumn{2}{|c|}{$\begin{array}{l}\text { by scrub method }\left(10^{5}\right) \text { after } \\
\text { bathing in }\end{array}$} \\
\hline & water & dilute detergent & water & dilute detergent \\
\hline $5 \mathrm{~min}$. before & 5 & 4 & $1 \cdot 2$ & $1 \cdot 0$ \\
\hline 5 min. after & 11 & 36 & 0.7 & $0 \cdot 3$ \\
\hline $5 \mathrm{hr}$ after & 4 & 16 & $1 \cdot 3$ & 0.9 \\
\hline $10 \mathrm{hr}$ after & 3 & 7 & $1 \cdot 2$ & $1 \cdot 1$ \\
\hline $25 \mathrm{hr}$ after & 4 & 5 & 1.05 & $1 \cdot 3$ \\
\hline
\end{tabular}

TABLE IV

Skin bacterial counts on babies before and after bathing with water and toilet soap

\begin{tabular}{|c|c|c|c|c|c|}
\hline \multirow{3}{*}{$\begin{array}{l}\text { Baby } \\
\text { (age) }\end{array}$} & \multirow{3}{*}{$\begin{array}{l}\text { Time } \\
\text { from bathing }\end{array}$} & \multicolumn{4}{|c|}{$\begin{array}{l}\text { Number of colony-forming units of micro-organisms } \\
\text { per } \mathrm{cm}^{2} \text { cultured }\end{array}$} \\
\hline & & \multicolumn{2}{|c|}{ by imprint method from } & \multicolumn{2}{|c|}{ by scrub method $\left(10^{5}\right)$ from } \\
\hline & & $\begin{array}{l}\text { interscapular } \\
\text { region }\end{array}$ & left axilla & $\begin{array}{l}\text { interscapular } \\
\text { region }\end{array}$ & left axilla \\
\hline \multirow[t]{3}{*}{ J. K. (1 mth) } & $5 \mathrm{~min}$. before & $3 \cdot 2$ & 24 & 0.027 & 35 \\
\hline & 5 min. after & $7 \cdot 2$ & 29 & 0.011 & 7 \\
\hline & $24 \mathrm{hr}$ after & 6.0 & 22 & 0.022 & 28 \\
\hline \multirow[t]{2}{*}{ M. S. $(5 \mathrm{mth})$} & $5 \mathrm{~min}$. before & $1 \cdot 1$ & 19 & 0.019 & 21 \\
\hline & $5 \mathrm{~min}$. after & $4 \cdot 8$ & $\begin{array}{l}35 \\
\text { (almost con- } \\
\text { fluent } \\
\text { growth) }\end{array}$ & 0.013 & 17 \\
\hline
\end{tabular}

count decreased five-fold. The older infant gave considerably increased colony counts at both these sites after washing, but relatively little diminution of the total scrub count. 


\section{Discussion}

Aerobic colony and bacterial counts from unwashed skin sites, by imprint and scrub procedures respectively, revealed that each colony apparently originated from a cluster of bacteria often containing many thousand viable units. Table II shows that the cluster population varied considerably between different skin sites; on a hairless surface of the anterior forearm one colony apparently corresponded to 1000 viable bacterial units, whereas on the upper abdomen, one colony represented some 70,000 bacteria. The use of surfactant in the scrub procedure ensured that the bacterial suspension scrubbed from the skin removed maximal numbers of colony-forming units (Williamson and Kligman, 1965). Microscopic studies have shown that in surfactant fluid these units sometimes consisted of as few as two bacteria, whereas elution in fluids containing no surfactant resulted in considerably larger clumps; surfactant scrub also washed more squamous cells from the surface, and freed more bacteria from each squame (Holt, 1969). Vigorous scrub procedures perhaps tend to exaggerate these findings by liberating bacteria from strata immediately below the skin surface, whereas the velvet-pad imprint method samples only those bacteria lying on the surface. More comparable values might result from the use of sticky-backed Cellophane-tape sampling (Thomas, 1961; Updegraff, 1964) to demonstrate viable aggregates in deeper skin layers.

The total aerobic bacterial counts obtained by the scrub method showed a marked decrease immediately after bathing, then returned to pre-wash numbers in $24 \mathrm{hr}$. This decrease was least pronounced when water alone was used for bathing, and was maximal when an anionic detergent was dissolved in warm bath water. Non-medicated toilet soap gave results midway between plain water and dilute detergent. In contrast, the detergent wash caused a nine-fold increase in the colonial count immediately after washing; before washing in this solution one replicate colony apparently corresponded to approximately 25,000 viable organisms. Soon after washing, one replicate colony appeared to correspond to fewer than 1000 organisms. Before firm conclusions are drawn from these experiments, they should be repeated with healthy subjects of both sexes and a wide age-range.

The combined effect of mechanical rubbing and presence of a surfactant during bathing could well account for many of the changes noted here. Although a considerable proportion of the surface bacteria may be removed into the bath water, as in Price's experiments (1938), the remaining surface bacteria could be spread more evenly over the skin, possibly by dispersal of large resident microcolonies into much smaller aggregates, each one of which was nevertheless capable of originating an imprint colony. This explanation is undoubtedly oversimplified and falls short of explaining the interplay of many other factors that must be considered. These include the discharge of organisms from sweat and sebaceous glands, the flow and altered characteristics of sebum in a hot bath, and the removal of sebum and surface lipids by hot water; the removal of outer layers of skin squames would expose younger squamespossibly heavily colonised by bacteria-which would be included in the postwash counts. These factors, and doubtless others not mentioned, would exert 
in combination wholly incalculable effects on the number and distribution of skin bacteria.

Removal of skin fatty acids by hot water and surfactant may cause a temporary imbalance between the inhibitory action of these compounds and growth of bacteria on the skin surface (Burtenshaw, 1938, 1942; Ricketts et al., 1951). It may be significant that in some experiments reported above the total bacterial count 10-24 hr after the wash was considerably higher than the pre-wash count; it perhaps takes a day or more for initial concentrations of skin lipids to be re-established to a level at which they can exert some controlling effect upon growth of skin flora. Concentrations of sebum and fatty acids may also have a bearing on relative sizes of bacterial aggregates or microcolonies on the skin. The work of Scheimann et al. (1960) suggests that the free fatty acids that exert some antibacterial activity on the skin surface are the result of lipolysis of sebum caused by bacteria. It could therefore be argued that removal of lipolytic bacteria by washing would temporarily diminish the concentration of the free fatty acids, despite the increased concentration of unsplit sebum. For some hours after bathing, surviving skin bacteria might multiply relatively unhindered by fatty acids, and freshly arrived transient bacteria might also luxuriate in a non-inhibitory environment.

Lacey (1968) showed large and significant increases in replicate culture counts of Staph. aureus suspensions allowed to dry for $5 \mathrm{hr}$ on human forearm skin after the skin had been treated with fat solvents. The action of the fat solvent may resemble that of soap or detergents, causing the separation of bacterial aggregates into smaller units, thus yielding higher replicate culture counts. Results from concurrent use of an elution count method would have been of considerable interest.

Speers et al. (1965) found marked increases in bacterial air counts sampled close to naked volunteers after showering for $10 \mathrm{~min}$.; an ordinary toilet soap was used. The slit-sampler used in their experiments distributed bacterial aggregates from the skin on blood-agar plates; these aggregates were either alone or carried on detached squames. Here again the resulting colony-count was not a true reflection of the total number of individual bacteria dispersed into the air from the bathed skin surface, but bore an inverse relation to the number of bacteria aggregated into each colony-forming unit. The larger the unit, the lower was the colony count, although the total number of bacterial cells projected by the slit-sampler on a given area of agar plate may have been higher. Had the volunteers showered with a dilute detergent even higher colony counts might have resulted from the smaller colony-forming units. These shower-bath experiments and those of other workers (Bethune et al., 1965; Cleton, van der Mark and van Toorn, 1968) are susceptible to the same interpretation as that offered for the bathing experiments reported here. Washing, particularly when vigorous and performed with a dispersant, causes the separation of large bacterial aggregates on the unwashed skin into much smaller colony-forming units. Many of these will be detached to give high elution counts by scrub-sampling, and many will become airborne to give high air colony-counts, yet sufficient will remain to give higher replicate counts than 
those recorded before washing. The realisation that all counts of skin bacteria are sampled from large aggregates of micro-organisms, that each aggregate is readily divisible into vast numbers of separate colony-forming units in both the elution and replication counting methods, and that the degree of segregation depends heavily upon the physical conditions of sampling, requires that much published work in this field should be re-appraised. Some of the conclusions from the published work appear to be based on the conception that bacteria are distributed discretely on the skin surface as individual viable cells.

It remains to be shown whether the hazard of airborne infection by liberation of organisms from the skin depends more on the number of contaminated particles or on the absolute number of bacteria that are released.

\section{SUMMARY}

Liquid-elution counts in a non-ionic surfactant and imprint replicate counts with velvet pads were used to investigate the changes in total bacterial and colony counts on normal skin surfaces after bathing with water, soap, or detergent. The experiments revealed that the total bacterial count on several skin sites was reduced soon after washing, returning in $24 \mathrm{hr}$ to the pre-wash numbers. In contrast, the colonial count from the same sites increased considerably after washing, again returning to the pre-wash count.

An explanation is offered that both kinds of counts were sampled from extremely large aggregates of bacteria on the skin surface, and that these aggregates could be segregated into very much smaller viable units, each still capable of originating individual colonies by either counting method. It is suggested that the extent of separation depended on the mechanical processes of washing, the presence of surface-active agents in the washing water, and the use of a non-ionic surfactant in the sampling and subsequent counting procedure.

It is a pleasure to acknowledge the helpful advice and encouragement from Dr R. L. Newman, Director of Studies for this programme, Dr W. C. Noble, Dr M. T. Parker, and Dr G. B. Hill, Medical Statistician, Registrar-General's Office.

\section{REFERENCES}

Bethune, D. W., Blowers, R., Parker, M., ANd Pask, E. A. 1965. Dispersal of Staphylococcus aureus by patients and surgical staff. Lancet, 1,480 .

Burtenshaw, J. M. L. 1938. The mortality of the haemolytic Streptococcus on the skin and on other surfaces. J. Hyg., Camb., 38, 575.

BURTENSHAW, J. M. L. 1942. The mechanism of self-disinfection of the human skin and its appendages. J. Hyg., Camb., 42, 184.

Cleton, F. J., VAN DER MARK, Y.S., AND VAN TOORN, M. J. 1968. Effect of shower-bathing on dispersal of recently acquired transient skin flora. Lancet, 1, 865.

Davies, R. R., AND Noble, W. C. 1962. Dispersal of bacteria on desquamated skin. Lancet, 2, 1295.

Davies, R. R., AND Noble, W. C. 1963. Dispersal of staphylococci on desquamated skin. Lancet, 1, 1111.

Gale, D., Broderick, E. G., LAMB, BetTy J., AND TOPPER, Rosemary 1962. Re-evaluation of scrub technic for preoperative disinfection of the surgeon's hands. Ann. Surg., 155, 107. 
Holt, R. J. 1966. Pad culture studies on skin surfaces. J. Appl. Bact., 29, 625.

Holt, R. J. 1969. Studies on the microflora of the normal human skin. Ph.D. Thesis, Council for National Academic Awards, London.

Kuigman, A. M. 1965. The bacteriology of normal skin. In Skin bacteria and their role in infection, ed. by H. I. Maibach and G. Hildick-Smith, New York, p. 13.

LACEY, R. W. 1968. Antibacterial action of human skin. In vivo effect of acetone, alcohol and soap on behaviour of Staphylococcus aureus. Br. J. Exp. Path., 49, 209.

Miles, A. A., MisRa, S. S., AND IRwIN, J. O. 1938. The estimation of the bactericidal power of the blood. J. Hyg., Camb., 38, 732.

Pachtman, E. A., Vicher, E. E., ANd BrunNer, M. J. 1954. The bacteriologic flora in seborrheic dermatitis. J. Invest. Derm., 22, 389.

Pillsbury, D. M., AND Kligman, A. M. 1954. Some current problems in cutaneous bacteriology. In Modern trends in dermatology, 2nd series, ed. by R. M. B. MacKenna, London, p. 187.

PrICE, P. B. 1938. The bacteriology of normal skin; a new quantitative test applied to a study of the bacterial flora and the disinfectant action of mechanical cleansing. J. Infect. Dis., 63, 301.

Ricketts, C. R., Squire, J. R., Topley, Elizabeth, and Lilly, H. A. 1951. Human skin lipids with particular reference to the self-sterilising power of the skin. Clin. Sci., 10, 89.

ScheimanN, Lois G., Knox, Grace, Sher, D., AND Rothman, S. 1960. The role of bacteria in the formation of free fatty acids on the human skin surface. J. Invest. Derm., 34, 171.

Speers, R., JR, Bernard, H., O'Grady, F., AND Shooter, R. A. 1965. Increased dispersal of skin bacteria into the air after shower-baths. Lancet, $1,478$.

Thomas, MaIr 1961. The sticky film method of detecting skin staphylococci. Mon. Bull. Minist. Hlth, 20, 37.

UPDEGRAFF, D. M. 1964. A cultural method of quantitatively studying the microorganisms in the skin. J. Invest. Derm., 43, 129.

Williamson, P., AND Kligman, A. M. 1965. A new method for the quantitative investigation of cutaneous bacteria. J. Invest. Derm., 45, 498. 